\title{
Contribution of the interpersonal communication toward problem solving strategies of high school students
}

\author{
Minarsi $^{1}$, Herman Nirwana ${ }^{2}$, Yarmis ${ }^{3}$ \\ ${ }^{123}$ Universitas Negeri Padang, Padang - Indonesia, minarsi24@yahoo.co.id
}

\begin{abstract}
This research was conducted from the student low level toward student problem solving strategies. The student problem solving strategies were affected by interpersonal communication. This research was intended to describe the contribution of the interpersonal communication toward student problem solving strategies. This correlational descriptive research applied quantitative methods. The sample of this research were 240 students of SMA Negeri 2 Pariaman on grade XI and XII, students there were chosen by proportional stratified random sampling technique. The instrument of the research was a questionnaire interpersonal communication inventory and problem solving strategies inventory. The data obtained were analyzed by using descriptive statistic, simple regression. The research findings that the interpersonal communication contributed on toward student problem solving strategies, The implications of the results of this study can be used as advice to School Counselor in providing guidance and counseling services.
\end{abstract}

Keywords: interpersonal communication, problem solving strategies

\section{Introduction}

Students are faced with various problems that demanded the resolution of problems, ranging from the simple to the most complex problems. In problem solving, students are often faced with difficult and sometimes a possible solution cannot be obtained immediately.

The problem usually contains thing encourage the students to finish it but they are unable to complete it directly. If students have problems and they able to find out how to get the solutions properly, it can be said they can to resolve the problem.

For students who do not have the readiness to face the problems, they often feel depressed and overshadowed by a growing problem. Students sometimes take the wrong decisions or move away from the problems. The problem, in fact is the gap between reality and what is expected. That gap presens in the form of complaints, disquiet, werries, or anxiety. To develop students ' ability in problem solving, it needs to be improved the ability that concerns to the various problem-solving strategies. In solving the problem, students being require the ability to decipher those parts so that it can eventually resolve the problems faced. In addition, to gain skills in problem solving, students must also have a lot of experience in solving various problems. 
Ability of problem solving is one of the objectives or competencies that will be achieved in learning. Problem solving as a destination and as a process is important in learning activities, problem-solving ability gained in General can be transferred for use in solving other problems. Problem solving involves some information and to obtain the settlement it used those information.

As described above, in problem solving requires a strategy. Problem solving strategy is a problemsolving process that concerns to the actual condition change into the condition desired. Problem solving strategy is a strategy of learning which is based on the large number of problems that need authentic investigation i.e. investigation requires completion of the problem at hand. Purwanto (1999:284) "strategy of problem solving is a process with use strategies, the way, or specific techniques for dealing with new situations, so that the situation can be undertaken in accordance with the predetermined desire". So the strategy of problem solving is a learning strategies that enable or train students to be able to face the problem and solve it.

Problem solving strategy directs the student's capability, good will, the feeling, the passion, and the most important is thought in solving the problems. This strategy encourages students to think systematically by facing them to the issues. It is important in their life confronting the problem. By problem solving strategy, student learning to develop the pattern their thought in finding solutions to every problem.

According to Weney \& Oemar (1980:755), "solving the problem is the interaction between stimulus and response, is a two-way relationship between learning and the environment". Environment gives feedback to students in the form of aid or issues, while the brain functioning nervous system interprets the assistance effectively so that the problems encountered can be investigated, analyzed and assessed, sought a resolution with either. The experience of student obtained from environment will serve as material and material in order to gain understanding and can be used as a guideline and the purpose of their learning.

Research conducted by Nuzliah (2015) about problem solving students in the study, as a whole noted on low earnings category score with the average of score is 56.24. Research conducted by Dewi (2015) about problem-solving ability of students in guidance and Counseling program study at Sriwijaya University found that the most of the problem-solving ability score is at a low category much as $41 \%$, in middle categories as much as $38.1 \%$, very high category as much as $14.3 \%$. Further research done by Prihatana (2012) regarding the strategy of problem-solving of teenagers various on models of learning noted that the acceleration class using problem solving in general are in the category are as much $30.8 \%$.

Based on the above phenomenon related to the students ability in problem solving is indeed as a very important thing in everyone's daily life, especially at high school student. A problem that occurs when finding students who feel confused and incapable of solving problems in arranging a clear plan (planful problem solving), looking for informational support, and planning issues through positive actions (confrontive coping).

The inability of students to find problem-solving strategies will yield behavior of shy away from the issue. If this is done, then the student's problems will not be resolved properly, will even be growing. Data obtained from the teacher's guidance and Counselling SMA Negeri 2 Pariaman i.e. many students haven't been able to find problem-solving strategies, where students were difficult to troubleshoot problems in the association with peers, students are more likely to own in doing a variety of activities without accompanied by my peers.

Based on some concept of problem-solving strategies above, is a problem-solving strategy in this research is a learning strategies that enable students and trained to deal with various problems and can looking for a workaround or a solution of the problem at hand. 
Based on the above research can be understood that when encountering problems, students haven't been able to find and resolve problems that are being experienced, this can be caused because of the many factors that affect the process of solving the problem. I.e. interpersonal communication. Interpersonal communication related to how individual behavior and satisfaction satisfy needs to interact with other people. As the opinions expressed Muuss (in Erozkan, 2013), During adolescence, communication with other people is very important for adolescents. During his teens, communication with others is very important. Furthermore, Erozkan (2013:739), stating that:

Communication is one of the most basic elements of human functioning, because it is the cornerstone of strong, healthy interpersonal relationship. Interpersonal relationship begin and develop through communication. The quality of communication has a direct impact on the quality of the interpersonal relationships.

The meaning contained in the sentence above, that communication is one of the basic elements of human functioning, because this is the basis of power in interpersonal relationship. Interpersonal relationships begin and evolve along with communicating. Quality of communications directly impact the quality of interpersonal relationships. Communication is very important in establishing interpersonal relationships, where interpersonal relationships support ability to use in personal interaction and understand other people effectively.

Based on theory and research results presented earlier there is the existence of variation about the level of problem-solving ability of the students. Affordable level of problem solving students alleged to be caused by several factors such as interpersonal communication. Therefore, scientific research needs to be done.

\section{Method}

This research included in the quantitative descriptive research. According to Joseph (2014) a descriptive quantitative research is one of the types of research that aims to describe the systematic, factual, and accurate about the fact and the nature of certain populations, or attempt to describe the phenomenon in detail ". The population in this research is a student of class X, and XI Senior High School No 2 Pariaman, with a total population of 601 students. sampling in this study using Proportional Stratifed Random Sampling, the sample amount of research as much as 240 students.

The instruments used are questionnaire. The validity of the test result of interpersonal communication is 0.421 , and problem-solving strategies of students of 0.443 . Reliability test results of interpersonal communication instruments 0.802 , and problem-solving strategies of students of 0.717 . Data were analyzed with descriptive statistics and simple regression.

\section{Results and Discussion}

1. Interpersonal Communication Regression Coefficient Test on Problem Solving Strategy

\begin{tabular}{ccc}
\hline Variabel & $\boldsymbol{R}$ & $\boldsymbol{R}$ Square \\
\hline $\mathrm{X}-\mathrm{Y}$ & 0.136 & 0.018 \\
\hline
\end{tabular}

Shows that the $\mathrm{r}$ value of 0.136 , which shows the regression coefficient of interpersonal communication to problem solving strategy. The value of R Square (R2) of 0.018 means $1.8 \%$ of the magnitude of the contribution of interpersonal communication to the problem-solving strategy.

2. Results of Simple Regression Analysis of Interpersonal Communication-Problem Solving Strategy Variables.

Once known regression coefficient and contribution of interpersonal communication to problem solving strategy. Furthermore can know the simple regression equation can be seen in Table. 


\begin{tabular}{cccc}
\hline Variabel & $\begin{array}{c}\text { Unstandardized } \\
\text { Coefficients }\end{array}$ & $\mathbf{T}$ & Sig. \\
\cline { 2 - 3 } & $\mathbf{B}$ & & \\
(Constant) & 87.646 & 11.901 & 0.000 \\
$\mathbf{X}$ & .174 & 2.116 & 0.035 \\
\hline
\end{tabular}

Simple regression results in table shows that $\mathrm{t}$ hitung $>\mathrm{t}$ tabel with $2.116>1.645$. This means communication interpersonal contributes to problem-solving strategies. The table above also illustrates the regression equation as follows.

$$
\begin{aligned}
& \tilde{Y}=a+b X 2 \\
& \tilde{Y}=0.17487,646+X 2
\end{aligned}
$$

The results showed that interpersonal communication contribute to problem-solving strategies. This interpersonal communication means related to a person's success in defining the strategies of problem solving. Interpersonal communication is very helpful to students in determining the strategy for solving the problem. Good communication to others will help students to make the planning or proper problem solving strategies.

Furthermore, in accordance with the opinion of the Lazarus \& Folkman (1984:163):

The ability to communicate and behave with others in ways that are socially appropriate and effective. Social skills facilitate problem solving in conjunction with other people, increase the likelihood of being able to enlist their cooperation or support, and in general give the individual greater control over social interactions.

That person's ability to find problem solving also determined how someone is able to communicate and behave with others. Social skills facilitate problem resolution with others, improving your chances of getting assistance and support, as well as in General give individuals great control over social interactions that do.

Students who have good interpersonal communication with others will tend to be able to organize problem-solving strategies that are being experienced. This indicates that, if the students have good communication, then students are likely to be easy in determining the strategy of problem solving. Interpersonal communication will be coloring how students define the strategies of problem solving. The better interpersonal communication students, then it is likely the better anyway students in determining the strategies of solving the problem. Although the influence of interpersonal communication towards a strategy of solving the problems of the weak students, this means there are still other factors that also affect the strategies of problem solving. These factors include personal factors and situational factors.

Most students can do a good interpersonal communication but some haven't been able to do for interpersonal communication. The inability to conduct interpersonal communication to problems experienced can be due to several things including: (1) the issue of preferred share knowledge itself, (2) there is no place to tell you about a problem that is experienced, (3) lack of self disclosure on the issue (Nirvana, 2012), (Ifdil, 2013), (4) assume that the issue need not be resolved, and (5) the existence of a cultural influence in solving problems (Robetson, 2001).

Based on the above explanation, so it can be understood that once the importance of having a strategy of problem solving. One of which must be improved and developed in every individual is interpersonal communication. On the interpersonal communication of this research are already in the right category. Therefore, teacher or Counsellor needs to improve the strategy of problem solving, interpersonal communication in advance for repair. One of the services that could be implemented to improve and develop interpersonal communication is a service of the information and guidance of the group. This is in accordance with the research conducted by Sukma \& Pratiwi (2013) revealed that 
the information and guidance of the group is applied to students can enhance interpersonal communication students toward good.

Furthermore, a service that can be implemented to improve and develop interpersonal communication is the counselling service group and individual counseling. This is in accordance with the research conducted by Marnita, Ahmad \& Said (2014) revealed that individual counseling and group counseling applied to students to effectively improve interpersonal communication students. Next services that could be implemented to improve and develop interpersonal communication is a tutoring service of classical. This is in accordance with the research conducted by Padmomartono \& Kesitawahyuningtyas (2014) reveals that the guidance applied to students of classical effectively to improve interpersonal communication students. And services that could be implemented to improve and develop interpersonal communication is information, orientation, guidance and counseling group of individuals. This is in accordance with the research conducted by Sahputra, Syahniar \& Marjohan (2016) revealed that the information services, orientation, guidance and counseling group of individuals who applied to the students to effectively improve communications interpersonal students.

\section{Conclusions}

The analysis results have been described, . the student's problem solving Strategies are on agood category so it can be said that senior high school no 2 Pariaman are already able to solve problems experienced, interpersonal Communication is at a good category so it can be said that senior high school no 2 Pariaman was able to build a good interpersonal communication to solve problems experienced, and interpersonal Communication contributes to problem-solving strategies of students. That is, problem-solving strategy low high students are also influenced by interpersonal communication. It can be concluded that, the better interpersonal communication students then will be the higher the student's problem solving strategies.

\section{References}

Chang, E. C., D'Zurilla, T. J., \& Sanna, L. J. (2004). Social Problem Solving Theory, Research, and Training. Washington, DC:American Psychological Association.

Deniz, M. E., \& Ersoy, E. (2016). Examining the Relationship of Social Skills, Problem Solving and Bullying in Adolescents.International Online Journal of Educational Sciences, 8 (1),1-7.

Devito, J. A. (2011). Komunikasi Antarmanusia. Terjemahan oleh Agus Maulana. Pamulang: Karisma Publishing Group.

Dewi, S. R. (2015). Hubungan Antara Konsep Diri Akademik dan Kemandirian Belajar dengan Kemampuan Pemecahan Masalah pada Mahasiswa Program Studi Bimbingan dan Konseling di Universitas Sriwijaya. Tesis tidak diterbitkan. Padang: UNP.

Effendi, U. O. (2007). Ilmu Komunikasi. Bandung: Remaja Rosdakarya.

Erozkan, A. (2013). The Effect of Communication Skills and Interpersonal Problem Solving Skills on Social Self-Efficacy. Journal Educational Sciences: Theory \& Practice, 13 (2), 739-745.

Lazarus, R. S., \& Folkman, S. (1984). Stress, Appraisal, and Coping. New York: Springer Publishing Company.

Marnita, W., Ahmad, R., \& Said, A. (2014). Komunikasi Interpersonal Siswa Pengguna Internet dan Implikasinya terhadap Layanan Bimbingan dan Konseling. Jurnal Konseling dan Pendidikan, 2(1), 8-14.

Nirwana, H. 2012. Pengungkapan Diri Siswa Sekolah Menengah dan Implikasinya Bagi Konseling. Jurnal Ilmu Pendidikan, 18(1), 1-7. 
Ormrod, E. J. 2008. Psikologi Pendidikan Membantu siswa tumbuh dan berkembang (edisi ke enam). Jakarta: Erlanga.

Padmomartono, S., \& Kesitawahyuningtyas, T. M. 2014. Meningkatkan Komunikasi Interpersonal melalui Layanan Bimbingan Klasikal. Jurnal Satya Widya, 30 (2), 63-70.

Pratiwi, W, S., \& Sukma, D. 2013. Komunikasi Interpersonal Siswa di Sekolah dan Implikasinya terhadap Pelayanan Bimbingan dan Konseling. Jurnal Ilmiah Konseling, 2 (1), 324-329.

Prihatana, R. D., Latifah, M., \& Johan, I. R. 2012. Konsep Diri, Kecerdasan Emosional, Tingkat Stres, dan Strategi Koping

Remaja pada Berbagai Model Pembelajaran. Jur.Ilm.Kel \& Kons, (Online), 5 (1),48-57.

Pontoh, P, W. 2013. Peranan Komunikasi Interpersonal Guru dalam Meningkatkan Pengetahuan Anak. Journal "Acta Diurna" 1(1), 1-11.

Purwanto, M. N. 2007. Psikologi Pendidikan. Bandung: Remaja Rosdakarya.

Purwanto, E. 1999. Desain Teks untuk Belajar "Pendekatan Pemecahan Masalah". Jurnal IPS dan Pengajaran. 33 (2): 284.

Rakhmat, J. 2007. Psikologi Komunikasi. Bandung: Remaja Rosdakarya.

Safitri, N., Neviyarni, S., \& Irianto, A. 2014. Efektivitas Layanan Bimbingan Kelompok untuk Meningkatkan Motivasi Belajar dan Mengurangi Perilaku Membolos Siswa. Jurnal Konselor, 3 (4), 180-195.

Sahputra, D., Syahniar., \& Marjohan. 2016. Kontribusi Kepercayaan Diri dan Kecerdasan Emosi terhadap Komunikasi Interpersonal Siswa serta Implikasinya dalam Pelayanan Bimbingan dan Konseling. Jurnal Konselor, 5 (3), 182-193.

Santrock, J. W. 2007. Psikologi Pendidikan: Edisi ke Dua). Jakarta: Prenada Media Group.

Syukur, Y. 2000. Kepedulian Mahasiswa terhadap Masalah yang Alaminya (Studi terhadap Mahasiswa Universitas Negeri Padang yang Belum Pernah Konseling, Baru Konseling dan Sudah Konseling). Tesis tidak di terbitkan. Padang: Prodi S2 BK FIP UNP.

Weney \& Oemar. 1980. Enquiry discovery Pendekatan Pemecahan Masalah dalam Pengajaran IPS. Jakarta: Proyek Pengembangan Pendidikan Guru (P3G) Depdikbud.

Wismath, S., Orr, D., \& Zhong, M. 2014. Student Perception of Problem Solving Skills. Transformative Dialogues: Teaching \& Learning Journal, 7 (3), 1-17.

Yusuf, A. M. 2014. Metodde Penelitian Kuantitatif, Kualitatif dan Penelitian Gabungan. Jakarta: Prenadamedia Grup.

Zande, R. V., Warnock, L., Nikoomanesh, B., \& Dexter, K. V. 2014. Problem Solving Skills for Life and Careers: Art Education,20-27. 